\title{
MASS LOSS OF AND TEMPERATURE DISTRIBUTION IN SOUTHERN PINE AND DOUGLAS FIR IN THE RANGE $100 \mathrm{TO} 800^{\circ} \mathrm{C}$
}

\author{
M. H. Do and G. S. Springer* \\ Department of Mechanical Engineering and Applies Mechanics \\ The University of Michigan, Ann Arbor, Michigan 48109 \\ (Received May 31, 1983) \\ (Revised September 26, 1983)
}

\begin{abstract}
Southern pine and Douglas fir test specimens were placed in an over kept at either $100,160,245,400,600$, or $800^{\circ} \mathrm{C}$, and the center point temperatures and the mass losses of the specimens were measured as functions of exposure time. A model is described for calculating the temperature distribution in and the mass loss of wooden beams having rectangular cross sections. Comparisons were made between the data and the results of the model, and reasonable agreements were found between the measured and calculated temperatures and mass losses. Some tests were also performed to assess the effect of ambient oxygen concentration on the mass loss.
\end{abstract}

\section{INTRODUCTION}

AN IMPORTANT PART OF THE PYROLYSIS OF WOOD IS THE HEATING up of wood and the evaporation of volatiles from the material. The evaporation of volatiles is represented by a mass loss. In this paper the temperature response and mass loss of wood were investigated at surface temperatures in the range of 100 to $800^{\circ}$. Data are presented for southern pine and Douglas fir. These types of wood were selected for the tests because of their wide use as structural timber. A model is also described which can be used to calculate the temperature distribution

*Present address: Department of Aeronautics and Astronautics, Stanford University, Stanford, California 94305. 
in and the mass loss of wooden beams having rectangular cross sections.

\section{THE MODEL}

Heat transferred to wood increases the temperature inside the wood, causing the wood to pyrolyze and to form volatile vapors. These vapors originate in the pyrolysis zone and flow out through the char layer, resulting in a mass loss. Here a simple model is described for calculating the temperature distribution and the mass loss as a function of time.

The model is developed for the following problem. A rectangular slab of thickness a and width $b$ is exposed to radiant and convective heat fluxes (Figure 1). The slab is taken to be infinite in the $z$ direction so that the temperature inside the slab varies only in the $x$ and $y$ directions (the problem is two dimensional). Initially, (time $t=0$ ) the temperature $\mathrm{T}$ at every point inside the slab is known and is sufficiently low so that no significant chemical or physical changes (i.e. no pyrolysis) occur in the material. The slab is then exposed suddenly to known heat fluxes q. Both convective and radiant heat fluxes may contribute to the total heat transfer. The slab is well ventilated so that the combustion products released during heating are removed from the vicinity of the surface.

The law of conservation of energy for a small volume element dv inside the slab can be expressed as:

rate of change of Net rate of energy Net rate of energy Rate of energy energy in $\mathrm{dv}=$ transferred into + transferred into + liberated (or $d v$ by conduction $\quad d v$ by convection absorbed) in $\mathrm{dv}$

The heat capacities of the vapor and the water are small compared to the heat capacity of the solid. The heat liberated by the vaporization of
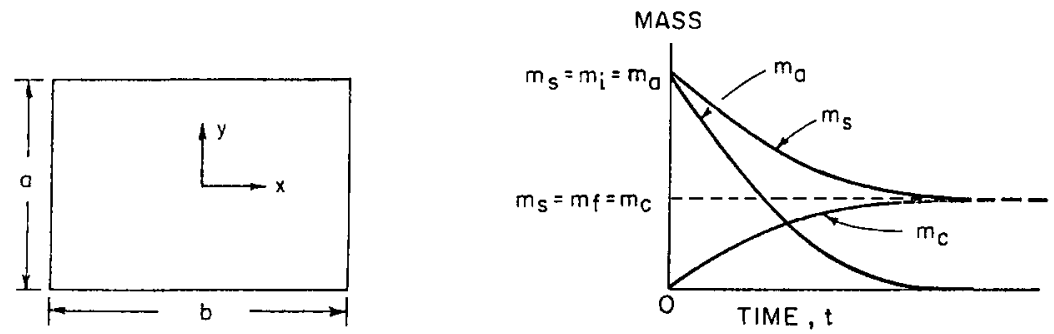

Figure 1. Geometry of the problem, and illustration of the variation of mass with time. 
water is small compared to the heat generated by the pyrolysis of the "active" wood. Finally, the heat transfer through the wood by convection is small compared to the heat transfer by conduction. Accordingly, the law of conservation of energy may be written as [1-20]

$$
\frac{\partial\left(m_{s} C_{s} T\right)}{\partial t}=\frac{\partial}{\partial x} K_{x} \frac{\partial T}{\partial x}+\frac{\partial}{\partial y} K_{y} \frac{\partial T}{\partial y}+\frac{\partial m_{a}}{\partial t} L
$$

where $T$ is the absolute temperature inside the material at the $x, y$ coordinate, $C_{s}$ is the specific heat (defined below), $L$ is the heat of reaction, $K_{x}$ and $K_{y}$ are the thermal conductivities in the $x$ and $y$ directions. $m_{s}$ is the mass per unit volume of the wood comprised of virgin ("active") wood (mass per unit volume $m_{a}$ ) and of wood which can not pyrolyze further at the given temperature ("inactive" wood, or "char", mass per unit volume $m_{c}$ )

$$
m_{s}=m_{a}+m_{c}
$$

$m_{s}, m_{a}$ and $m_{c}$ vary with time as illustrated in Figure 1 . The water content is not included in $m_{s}$.

Following the suggestion of Kang [20], the specific heat and the thermal conductivities are expressed as

$$
\begin{gathered}
C_{s}=\frac{m_{a}}{m_{s}} C_{a}+\frac{m_{c}}{m_{s}} C_{c} \\
K_{x, y}=\frac{m_{a}}{m_{i}} K_{a_{x, y}}+\frac{m_{c}}{m_{f}} K_{c_{x, y}}
\end{gathered}
$$

where $C_{a}, C_{c}$ and $\mathrm{K}_{a}, K_{\mathrm{c}}$ are the heat capacities and thermal conductivities of the active wood and char, respectively. $m_{i}$ and $m_{f}$ are the masses (dry wood) at the beginning and at the end of the pyrolysis

$$
\left.\left.\begin{array}{l}
m_{s}=m_{a}=m_{c}=\varrho_{a} \\
m_{\mathrm{c}}=0
\end{array}\right\} t<0 \quad \begin{array}{l}
m_{s}=m_{f}=m_{\mathrm{c}} \\
m_{a}=0
\end{array}\right\} t \rightarrow \infty
$$

$\varrho_{a}$ is the density of the dry, active wood. Note that $\varrho_{a}$ is a constant for a given type of wood. The mass $m_{f}$ depends upon the temperature. The value of $m_{f}$ decreases with increasing temperatures. The mass $m_{s}$ is related to $m_{i}$ and $m_{f}$ by the expression

$$
m_{s}=\left(1-\frac{m_{f}}{m_{i}}\right) m_{a}+m_{f}
$$


The expressions used for the specific heat, thermal conductivity, and mass (eqs. 3,4,6) are approximate only. The linear functions are adopted because detailed information on the behavior of these properties is unavailable. It is assumed that the volatile formation (and correspondingly the rate of change of mass of active wood) may be represented by a single step Arrhenius bulk reaction

$$
\frac{\partial m_{a}}{\partial t}=-m_{a} k_{a} e^{-E_{a} / R T}
$$

$k$ is the frequency factor, $E$ is the activation energy, and $R$ is the universal gas constant. The reactions occurring during the pyrolysis are complex. Therefore, $k_{a}$ and $E_{a}$ may be taken to be constants only within narrow temperature ranges. Values of $k_{a}$ and $E_{a}$ appropriate to the temperature must be used in the calculations.

The rate of water vapor formation is also represented by a single step Arrhenius bulk reaction

$$
\frac{\partial m_{w}}{\partial t}=-m_{w} k_{w} e^{-E_{w} / R T}
$$

The total mass lost (volatile plus water vapor) by the wood during time $t$ is

$$
\Delta m=\int_{0}^{t}\left(\frac{\partial m_{a}}{\partial t}+\frac{\partial m_{w}}{\partial t}\right) d t
$$

In order to obtain solutions to eqns. (1)-(9) the initial and boundary conditions must be specified. Initially $($ time $t=0$ ) the temperature of the wood $T_{1}$, the density of the wood $\varrho_{a}$, and the mass fraction $M$ of the water in the wood must be given

$$
\begin{aligned}
& m_{s}=m_{i}=m_{a}=\varrho_{a} \quad T=T, \\
& m_{c}=O \\
& m_{w}=M \varrho_{a}
\end{aligned}
$$

During pyrolysis (time $t>0$ ) either the surface temperature $T_{0}$ or the heat flux $q$ must be known at every point on the surface.

Solutions to the above problem can be obtained by numerical methods. A "user friendly" computer code suitable for generating numerical results was developed and can be obtained from the Department of Aeronautics and Astronautics, Stanford University. 


\section{RESULTS}

Temperature distributions in and mass losses of southern pine and Douglas fir specimens were calculated using the material properties listed in Tables 1-4. The initial water content $M$ was measured by drying $10 \mathrm{~cm}$ long, $2.54 \mathrm{~cm}$ wide, and $2.54 \mathrm{~cm}$ thick specimens in a circulating oven kept at $105^{\circ} \mathrm{C}$. The mass (weight) loss of each specimen during drying was followed by periodically weighing the specimens on a Mettler Analytical Balance. The moisture contents (average of 18 specimens) are listed in Tables 1-4.

The thermal conductivities of dry wood samples were measured at

Table 1. Material constants used in calculating the mass loss at $100^{\circ} \mathrm{C}$.

\begin{tabular}{lccccc}
\hline \multicolumn{1}{c}{ Constant } & Unit & $\begin{array}{c}\text { Southern } \\
\text { Pine }\end{array}$ & $\begin{array}{c}\text { Douglas } \\
\text { Fir }\end{array}$ & Source \\
\hline Density of active wood, $\mathrm{e}_{\mathrm{a}}$ & $\mathrm{kg} / \mathrm{m}^{3}$ & 547 & 365 & measured \\
Final mass, $\mathrm{m}_{\mathrm{f}}$ & $\mathrm{kg} / \mathrm{m}^{3}$ & 496 & 340 & from data \\
Specific heat of active wood, $\mathrm{C}_{\mathrm{a}}$ & $\mathrm{kJ} / \mathrm{kg}-\mathrm{K}$ & 2.30 & 2.30 & Kung 1972 \\
Specific heat of char, $\mathrm{C}_{\mathrm{c}}$ & $\mathrm{kJ} / \mathrm{kg}-\mathrm{K}$ & 1.013 & 1.013 & $\mathrm{Kung} 1972$ \\
Thermal conductivity of active wood, $\mathrm{K}_{\mathrm{a}}$ & $\mathrm{kJ} / \mathrm{m}-\mathrm{sec}-\mathrm{K}$ & 0.130 & 0.130 & measured \\
Thermal conductivity of char, $\mathrm{K}_{\mathrm{c}}$ & $\mathrm{kJ} / \mathrm{m}-\mathrm{sec}-\mathrm{K}$ & 0.188 & 0.188 & Haven 1972 \\
Heat of vapor generation, $\mathrm{L}$ & $\mathrm{kJ} / \mathrm{kg}$ & 2,510 & 2,510 & from data \\
Frequency factor of active wood, $\mathrm{K}_{\mathrm{a}}$ & $1 / \mathrm{sec}$ & 100,000 & 100,000 & from data \\
Frequency factor of water, $\mathrm{k}_{\mathrm{w}}$ & $1 / \mathrm{sec}$ & 2,000 & 2,000 & from data \\
Activation energy of active wood, $\mathrm{E}_{\mathrm{a}}$ & $\mathrm{kJ} / \mathrm{k} \mathrm{mole}$ & 85,000 & 85,000 & from data \\
Activation energy of water, $\mathrm{E}_{\mathrm{w}}$ & $\mathrm{kJ} / \mathrm{k}$ mole & 45,000 & 45,000 & from data \\
Intial mass fraction of water, $\mathrm{M}$ & - & 0.06 & 0.094 & measured \\
\hline
\end{tabular}

Table 2. Material constants used in calculating the mass loss at $160^{\circ} \mathrm{C}$.

\begin{tabular}{lcccc}
\hline \multicolumn{1}{c}{ Constant } & Unit & $\begin{array}{c}\text { Southern } \\
\text { Pine }\end{array}$ & $\begin{array}{c}\text { Douglas } \\
\text { Fir }\end{array}$ & Source \\
\hline Density of active wood, $\varrho_{a}$ & $\mathrm{~kg} / \mathrm{m}^{3}$ & 547 & 365 & measured \\
Final mass, $\mathrm{m}_{\mathrm{f}}$ & $\mathrm{kg} / \mathrm{m}^{3}$ & 496 & 340 & from data \\
Specific heat of active wood, $\mathrm{C}_{\mathrm{a}}$ & $\mathrm{kJ} / \mathrm{kg}-\mathrm{K}$ & 2.30 & 2.30 & Kung 1972 \\
Specific heat of char, $\mathrm{C}_{\mathrm{c}}$ & $\mathrm{kJ} / \mathrm{kg}-\mathrm{K}$ & 1.013 & 1.013 & $\mathrm{Kung} 1972$ \\
Thermal conductivity of active wood, $\mathrm{K}_{\mathrm{a}}$ & $\mathrm{kJ} / \mathrm{m}-\mathrm{sec}-\mathrm{K}$ & 0.130 & 0.130 & measured \\
Thermal conductivity of char, $\mathrm{K}_{\mathrm{c}}$ & $\mathrm{kJ} / \mathrm{m}-\mathrm{sec}-\mathrm{K}$ & 0.188 & 0.188 & Haven 1972 \\
Heat of vapor generation, $\mathrm{L}$ & $\mathrm{kJ} / \mathrm{kg}$ & 2,510 & 2,510 & from data \\
Frequency factor of active wood, $\mathrm{K}_{\mathrm{a}}$ & $1 / \mathrm{sec}$ & 60,000 & 60,000 & from data \\
Frequency factor of water, $\mathrm{k}_{\mathrm{w}}$ & $1 / \mathrm{sec}$ & 10,000 & 10,000 & from data \\
Activation energy of active wood, $\mathrm{E}_{\mathrm{a}}$ & $\mathrm{kJ} / \mathrm{k} \mathrm{mole}$ & 85,000 & 85,000 & from data \\
Activation energy of water, $\mathrm{E}_{\mathrm{w}}$ & $\mathrm{kJ} / \mathrm{k}$ mole & 45,000 & 45,000 & from data \\
Initial mass fraction of water, $\mathrm{M}$ & - & 0.06 & 0.094 & measured \\
\hline
\end{tabular}


Table 3. Material constants used in calculating the mass loss at $245^{\circ} \mathrm{C}$.

\begin{tabular}{lcccc}
\hline \multicolumn{1}{c}{ Constant } & Unit & Southern & Douglas & \\
& Pine & Fir & Source \\
\hline Density of active wood, $\mathrm{Q}_{\mathrm{a}}$ & $\mathrm{kg} / \mathrm{m}^{3}$ & 547 & 365 & measured \\
Final mass, $\mathrm{m}_{\mathrm{f}}$ & $\mathrm{kg} / \mathrm{m}^{3}$ & 400 & 340 & from data \\
Specific heat of active wood, $\mathrm{C}_{\mathrm{a}}$ & $\mathrm{kJ} / \mathrm{kg}-\mathrm{K}$ & 2.30 & 2.30 & Kung 1972 \\
Specific heat of char, $\mathrm{C}_{\mathrm{c}}$ & $\mathrm{kJ} / \mathrm{kg}-\mathrm{K}$ & 1.013 & 1.013 & Kung 1972 \\
Thermal conductivity of active wood, $\mathrm{K}_{\mathrm{a}}$ & $\mathrm{kJ} / \mathrm{m}-\mathrm{sec}-\mathrm{K}$ & 0.133 & 0.133 & measured \\
Thermal conductivity of char, $\mathrm{K}_{\mathrm{c}}$ & $\mathrm{kJ} / \mathrm{m}-\mathrm{sec}-\mathrm{K}$ & 0.188 & 0.188 & Haven 1972 \\
Heat of vapor generation, $\mathrm{L}$ & $\mathrm{kJ} / \mathrm{kg}$ & 2,510 & 2,510 & from data \\
Frequency factor of active wood, $\mathrm{k}_{\mathrm{a}}$ & $1 / \mathrm{sec}$ & 40,000 & 15,000 & from data \\
Frequency factor of water, $\mathrm{K}_{\mathrm{w}}$ & $1 / \mathrm{sec}$ & 100,000 & 100,000 & from data \\
Activation energy of active wood, $\mathrm{E}_{\mathrm{a}}$ & $\mathrm{kJ} / \mathrm{k} \mathrm{mole}$ & 85,000 & 85,000 & from data \\
Activation energy of water, $\mathrm{E}_{\mathrm{w}}$ & $\mathrm{kJ} / \mathrm{k} \mathrm{mole}$ & 45,000 & 45,000 & from data \\
Initial mass fraction of water, $\mathrm{M}$ & - & 0.06 & 0.094 & measured \\
\hline
\end{tabular}

Table 4. Material constants used in calculating the mass loss and the center point temperature at temperatures between 400 and $800^{\circ} \mathrm{C}$.

\begin{tabular}{lcccc}
\hline \multicolumn{1}{c}{ Constant } & Unit & Southern & Douglas & \\
& Pine & Fir & Source \\
\hline Density of active wood, $e_{\mathrm{a}}$ & $\mathrm{kg} / \mathrm{m}^{3}$ & 547 & 365 & measured \\
Final mass, $\mathrm{m}_{\mathrm{f}}$ & $\mathrm{kg} / \mathrm{m}^{3}$ & 125 & 125 & from data \\
Specific heat of active wood, $\mathrm{C}_{\mathrm{a}}$ & $\mathrm{kJ} / \mathrm{kg}-\mathrm{K}$ & 2.30 & 230 & Kung 1972 \\
Specific heat of char, $\mathrm{C}_{\mathrm{c}}$ & $\mathrm{kJ} / \mathrm{kg}-\mathrm{K}$ & 1.013 & 1.013 & Kung 1972 \\
Thermal conductivity of active wood, $\mathrm{K}_{\mathrm{a}}$ & $\mathrm{kJ} / \mathrm{m}-\mathrm{sec}-\mathrm{K}$ & 0.133 & 0.133 & measured \\
Thermal conductivity of char, $\mathrm{K}_{\mathrm{c}}$ & $\mathrm{kJ} / \mathrm{m}-\mathrm{sec}-\mathrm{K}$ & 0.188 & 0.188 & Haven 1972 \\
Heat of vapor generation, $\mathrm{L}$ & $\mathrm{kJ} / \mathrm{kg}$ & 1,255 & 1,255 & Kung 1972 \\
Frequency factor of active wood, $\mathrm{k}_{\mathrm{a}}$ & $1 / \mathrm{sec}$ & 7,700 & 9,400 from data \\
Frequency factor of water, $\mathrm{k}_{\mathrm{w}}$ & $1 / \mathrm{sec}$ & $1,000,000$ & $1,000,000$ from data \\
Activation energy of active wood, $\mathrm{E}_{\mathrm{a}}$ & $\mathrm{kJ} / \mathrm{k} \mathrm{mole}$ & 85,000 & 85,000 from data \\
Activation energy of water, $\mathrm{E}_{\mathrm{w}}$ & $\mathrm{kJ} / \mathrm{k} \mathrm{mole}$ & 45,000 & 45,000 from data \\
Initial mass fraction of water, $\mathrm{M}$ & - & 0.06 & 0094 measured \\
\hline
\end{tabular}

100 and $160^{\circ} \mathrm{C}$ using a parallel plate apparatus and the procedures specified by ASTM C 518-76 standard.

Mass losses and center point temperatures were calculated for different frequency factors and activation energies. The mass losses and temperatures thus calculated were compared to data. The values of the frequency factors and activation energies were selected which gave the best fit between the results of the model and the measured mass losses and center point temperatures. The frequency factors and activation energies obtained by this procedure are given in Tables 1-4.

In the calculations the surface temperatures were taken to be constant at either $100,160,245,400,600$, or $800^{\circ} \mathrm{C}$. 


\section{Comparisons between the Model and the Data}

The results of the model were compared to center point temperatures $\left(T=T_{c}\right.$ at $x=0$ and $\left.y=0\right)$ and to mass losses measured using southern pine and Douglas fir specimens. The mass loss is defined as

$$
m^{*}=\frac{\Delta m}{m} \times 100
$$

where $m$, is the initial mass of the specimen and $\Delta m$ is the mass loss (volatiles plus water vapor). The measurements were performed by placing $10 \mathrm{~cm}$ long specimens into a muffler oven. The mass loss was determined by keeping each specimen in the oven for a predetermined length of time and by measuring the weight before and after the exposure using a Mettler Analytical Balance. Each measurement was performed with a different specimen. Data were taken only with those specimens which did not flame in the oven.

The center point temperature was recorded by placing a chromelalumel thermocouple into the center of the specimen. Each data point in Figures 2 and 3 represents the average of two measurements performed using two different specimens.

Comparisons between the measured and calculated center point temperatures are presented in Figures 2 and 3. Comparisons between the measured and calculated mass losses are shown in Figures 4-11. The agreements between the measured and calculated center point temperatures and the measured and calculated mass losses are quite reasonable, especially when considering the limitations which, by necessity, were introduced in the calculations. The accuracies of the calculations are limited by simplifications in the analysis and by uncertainties in the physical constants. Nevertheless, the results of the model indicate the trend in the data and provide estimates of the mass loss.

This is of importance here since our primary goal in developing the model was to estai lish a tool which can nrovide a measure of the degradation proce $a$ and can thus be usec! in estimate changes in the strength of the woc 3 . For this purpose the results of the model appear to be adequate [22].

\section{Effect of Oxygen Concentration}

Tests were also performed to assess the influence of the ambient oxygen concentration on the mass loss. In these tests the oven was filled with either pure oxygen or with pure nitrogen. Mass losses were measured in these two environments at 100 and $245^{\circ} \mathrm{C}$. The results are shown in Figure 12. As one might expect, the mass loss is somewhat higher in the pure oxygen environment. However, the maximum dif- 
ference in the mass loss in pure oxygen and in pure nitrogen environments is only about 25 percent. This suggests that a small (few percent) change in the oxygen concentration of the air may not affect significantly the mass loss.

\section{ACKNOWLEDGEMENTS}

The authors wish to thank Messrs. D. A. Stanke and N. H. Jin for their help in the experiments. This work was supported by the Center for Fire Research, National Bureau of Standards, under Grant Number NB80NADA 1054.
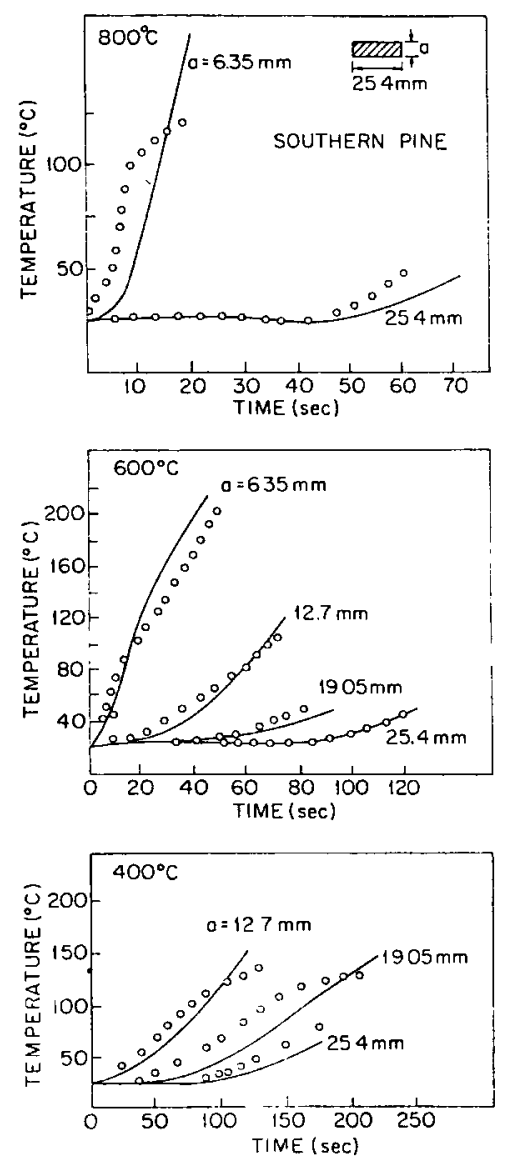

Figure 2. Center point temperature as a function of exposure time. Southern pine. $o$ Data, model. 

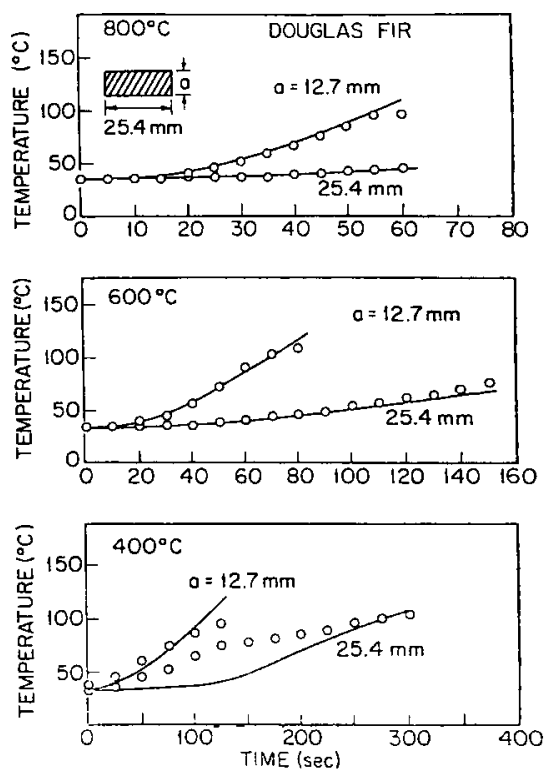

Figure 3. Center point temperature as a function of exposure time. Douglas fir. o Data, model.
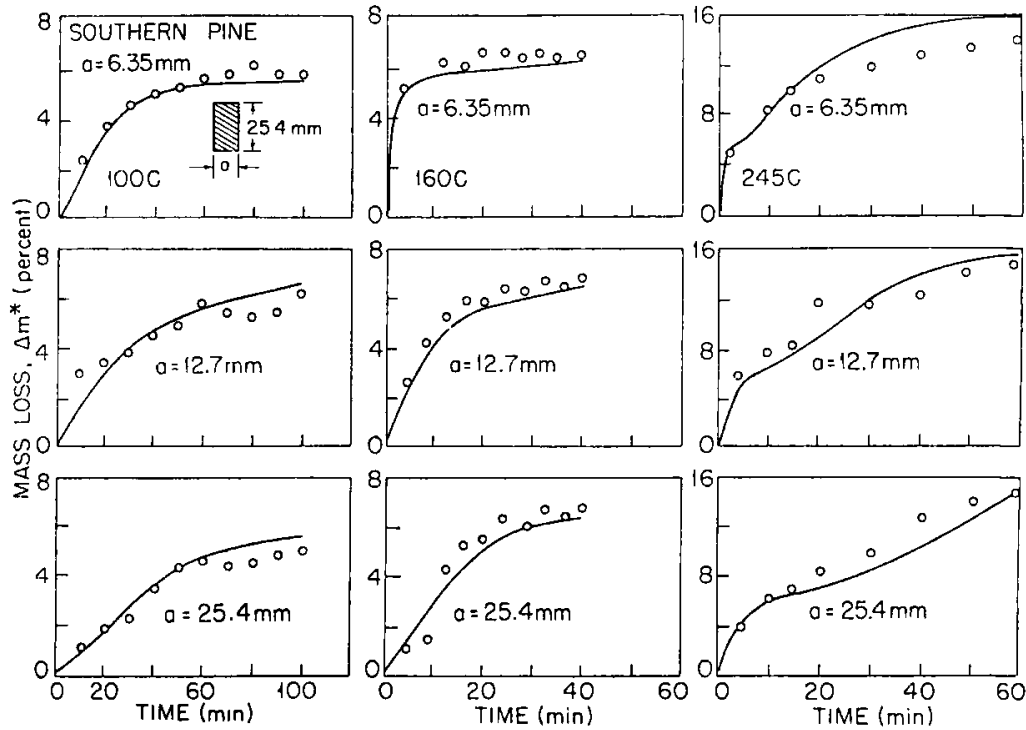

Figure 4. Mass loss as a function of exposure time. Southern pine at 100, 160 and $245^{\circ} \mathrm{C}$. o Data, model. 

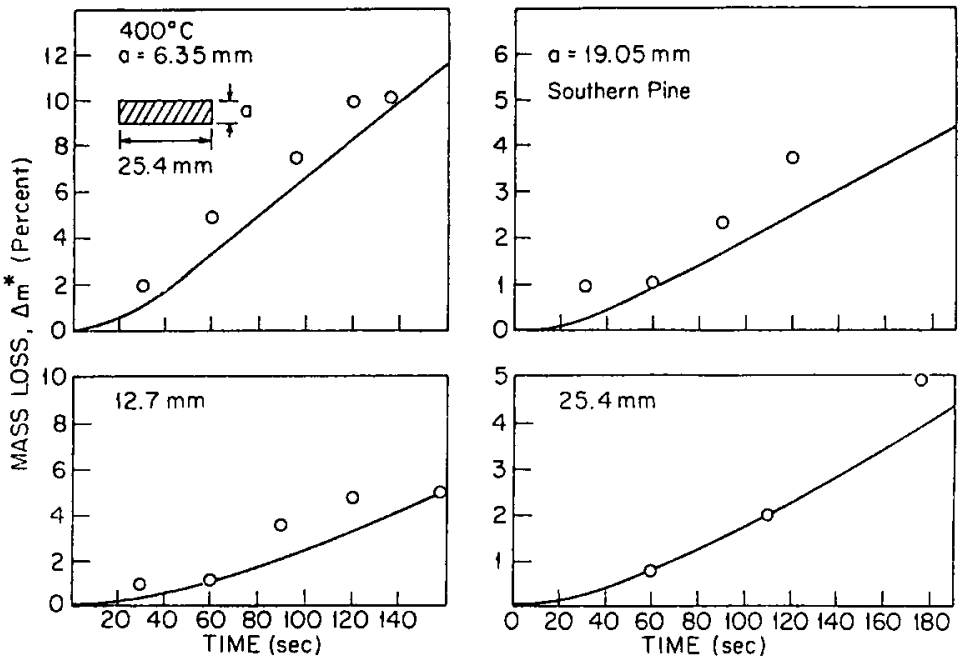

Figure 5. Mass loss as a function of exposure time. Southern pine at $400^{\circ} \mathrm{C}$. o Data, model.
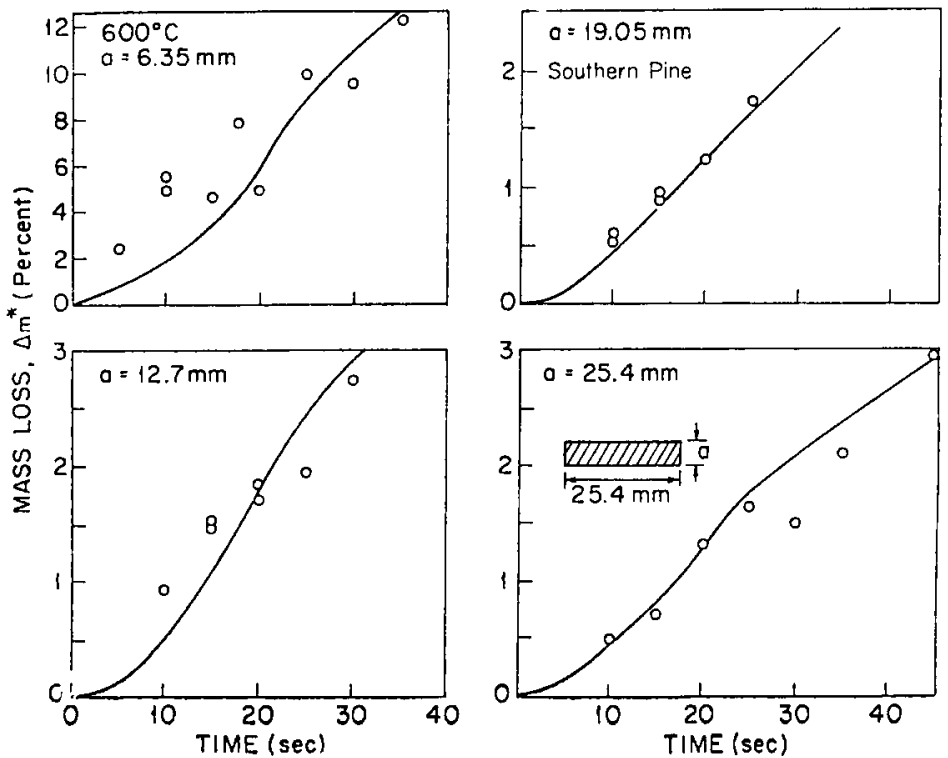

Figure 6. Mass loss as a function of exposure time. Southern pine at $600^{\circ} \mathrm{C}$. o Data, model. 

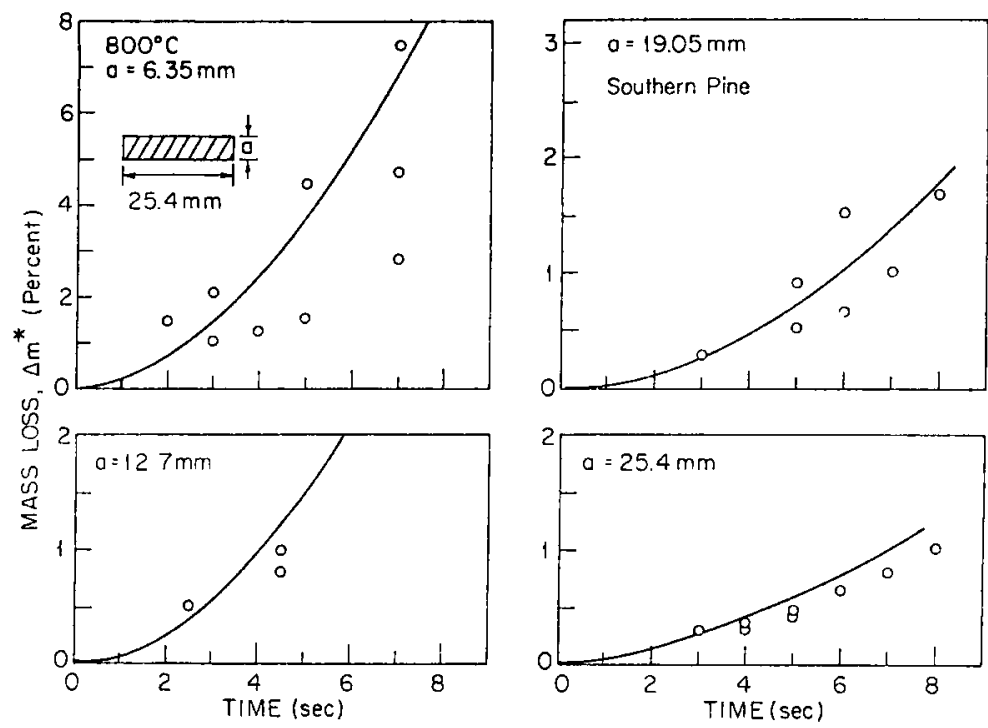

Figure 7. Mass loss as a function of exposure time. Southern pine at $800^{\circ} \mathrm{C}$. o Data, model.
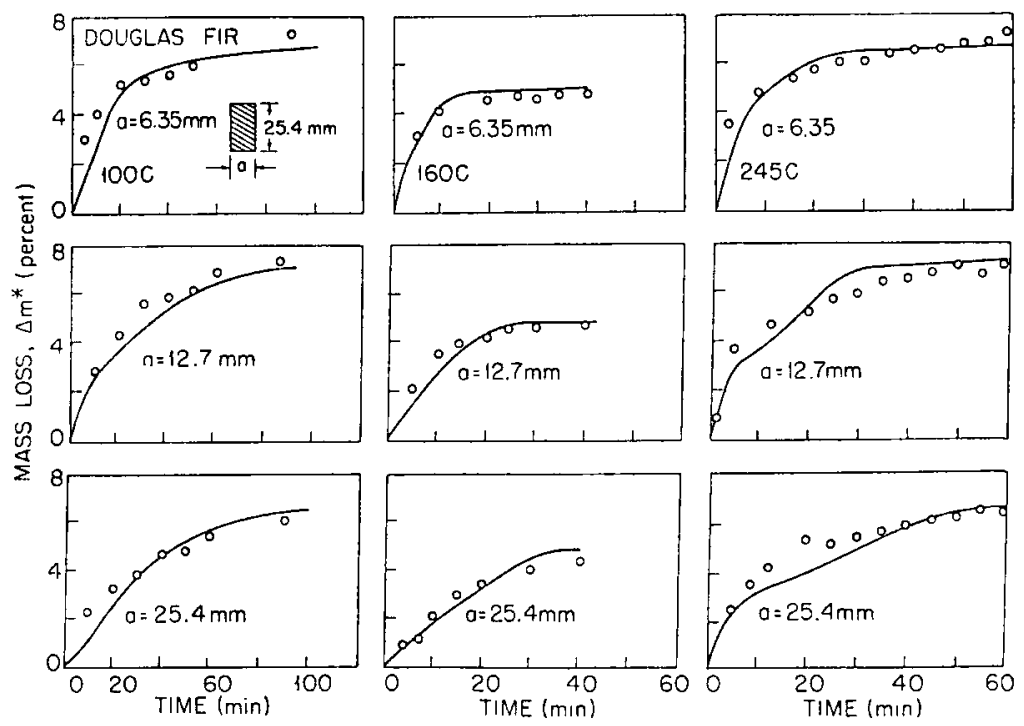

Figure 8. Mass loss as a function of exposure time. Douglas Fir at 100, 160 and $245^{\circ} \mathrm{C}$. o Data, model. 


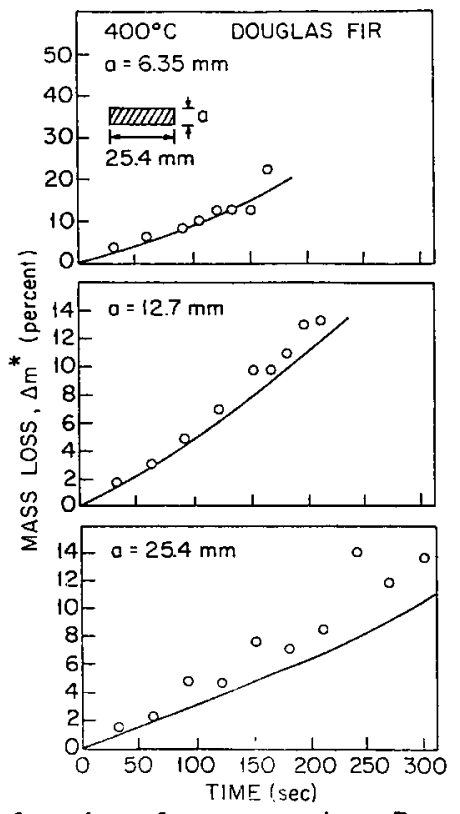

Figure 9. Mass loss as a function of exposure time. Douglas Fir at $400^{\circ} \mathrm{C}$. o Data, model.
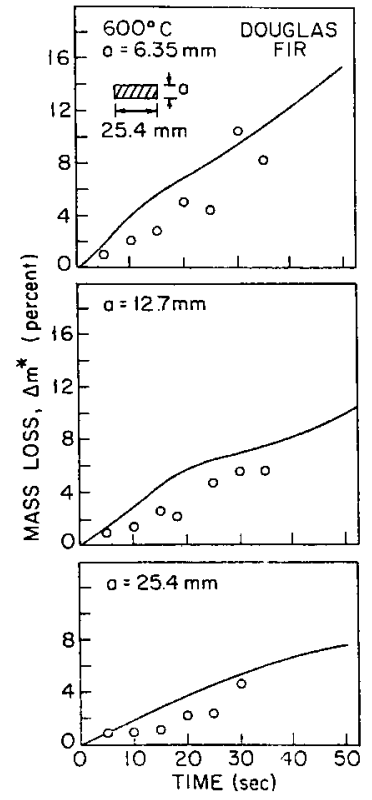

Figure 10. Mass loss as a function of exposure time. Douglas Fir at $600^{\circ} \mathrm{C}$. o Data, model. 


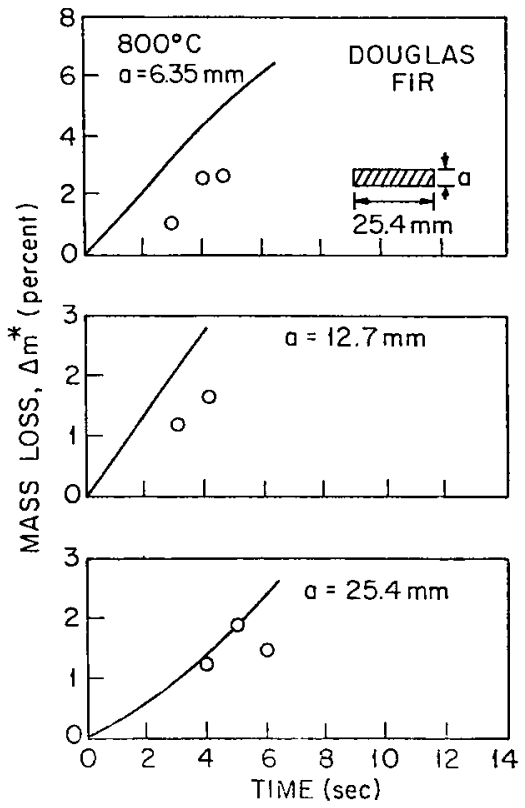

Figure 11. Mass loss as a function of exposure time. Douglas Fir at $800^{\circ} \mathrm{C}$. o Data, model.
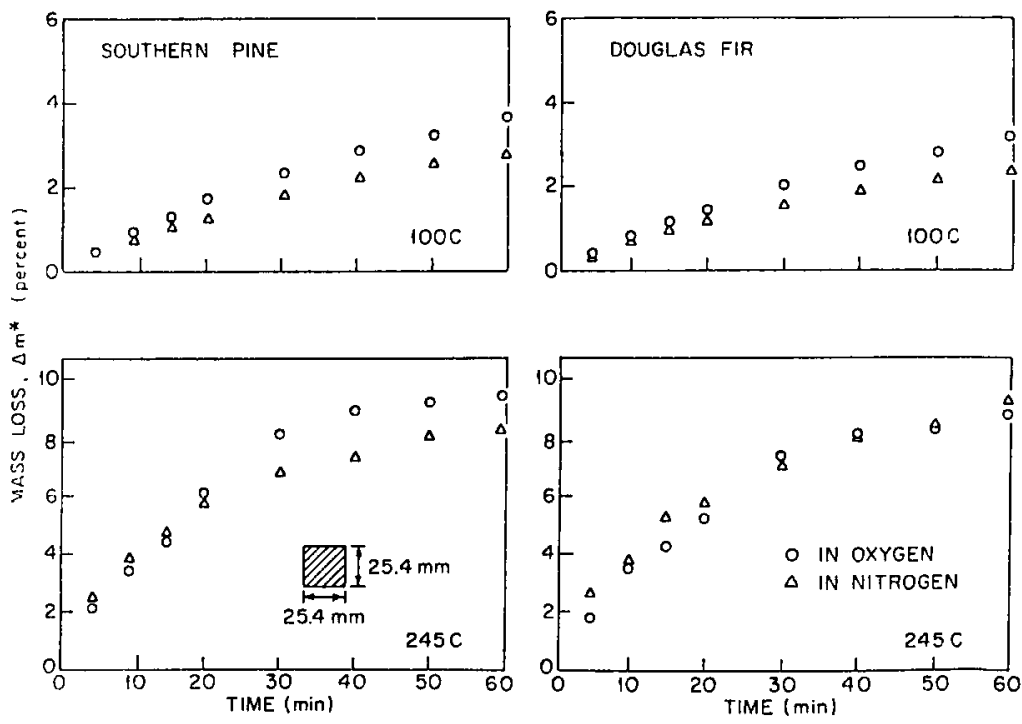

Figure 12. Mass loss as a function of exposure time with the wood immersed in pure oxygen or in pure nitrogen. 


\section{REFERENCES}

1. Pering, G. A., and Springer, G. S., Fire Technology, Vol. 16 (1980), p. 245.

2. Springer, G. S., Dastin, R. M., Do, H. M., Farrell, P. V., Humphries, D. R., and Stanke, D. A., Report to the Center for Fire Research, National Bureau of Standards (1981).

3. Adabbo, H. E., Rojas, A. J., and Williams, R. J. J., Polymer Engineering Science, Vol. 19 (1979), p. 835.

4. Broyer, E., and Macosko, C. W., AIChE Journal, Vol. 22 (1976), p. 268.

5. Progelhof, R. C. and Throne, J. L., Polymer Engineering Science, Vol. 15 (1975), p. 690.

6. Welker, J. R., Journal of Fire and Flammability, Vol. 1 (1970), p. 12.

7. Kosdon, S. J., Williams, F. A., and Buman, C., Twelfth Symposium (International) on Combustion, The Combustion Institute, Pittsburgh, PA (1969), p. 253.

8. Wolfe, V. L., and Durbetaki, P., ASME Paper 79-HT-27 (1979).

9. Barron, S., Journal of Fire and Flammability, Vol. 7 (1976), p. 387.

10. Brauman, S. K., Journal of Fire and Flammability, Vol. 8 (1977), p. 210.

11. Starett, P. S., Journal of Fire and Flammability, Vol. 8 (1977), p. 5.

12. Silvergleit, M., Morris, J. G., and Larosa, C. N., Polymer Engineering Science, Vol. 18 (1978), p. 97.

13. Lewellen, P. C., Peters, W. A., and Howard, J. B., Sixteenth Symposium (International) on Combustion, The Combustion Institute, Pittsburgh, PA (1977), p. 1471.

14. Kanury, A. M., and Holve, D. J., Journal of Heat Transfer, Vol. 101 (1979), p. 365 .

15. Weatherford, W. D., and Sheppard, D. M., Tenth Symposium International) on Combustion, The Combustion Institute, Pittsburgh, PA (1965) p. 897.

16. Anderson, W. H., Combustion Science and Technology, Vol. 2 (1970), p. 213.

17. Tinney, E. R., Tenth Symposium (International) on Combustion, The Combustion Institute, Pittsburgh, PA (1965) p. 925.

18. Kanury, A. M., Journal of Fire and Flammability, Vol. 2 (1971), p. 191.

19. Panton, R. L., and Rittman, J. G., Thirteenth Symposium (International) on Combustion, The Combustion Institute, Pittsburgh, PA (1971) p. 881.

20. Kung, H. C., Combustion and Flame, Vol. 18 (1972), p. 185.

21. Haven, J. A., Hashemi, H. T., Brown, L. E., and Welker, J. R., Combustion Sci. and Technology, Vol. 5 (1972), p. 91.

22. Do, M. H. and Springer, G. S., "Model for Predicting Changes in the Strengths and Moduli of Timber Exposed to Elevated Temperatures," Journal of Fire Sciences, Vol. 1, 1983, pp. 285-296. 